\title{
The Impact of Social Marketing Activities on Citizens' Attitudes Applied to the Vision of Saudi Arabia 2030
}

\author{
HANY ALY SHARED \\ Business Department, College of Science and Humanities, Shaqra University - KSA \\ E-mail: hshared@su.edu.sa / hshared@gmail.com
}

\begin{abstract}
The objective of the research is to identify the extent to which Saudi citizens understand the social marketing activities of KSA within the 2030 Vision and its impact on their attitudes. It explores also the impact of the demographic factors on the attitudes of the Saudi citizens within the scope of the KSA 2030 Vision. 200 sheets constituting the sample of the research have been analyzed. To achieve the objectives of the research, the researcher prepared a survey questionnaire which includes in its final shape (31) items. The validity of the questionnaire was tested by a committee of specialists. Also, the reliability of the questionnaire was tested using (Cronbach-Alpha) coefficient. The researcher used the statistical methods of arithmetical averages, standard deviations, and the ordinal importance of all the research variables and the components of each variable through the program (SPSS). The results of the research show that the social marketing activities of the KSA within the 2030 Vision have contributed to the influence of the citizens' attitudes on the vocabulary of the research sample, and that there is a difference in the attitudes of citizens about the KSA 2030 Vision in terms of demographic variables (age, income, educational levels). The research did not prove the difference in citizens' attitudes towards the KSA 2030 Vision in terms of (gender).
\end{abstract}

Keywords: Social Marketing, KSA 2030 Vision, Attitudes.

\section{Introduction}

In the context of achieving the sustainable development pursued by most States to prepare, and the transition to the third millennium with better aspirations for future generations. The Saudi government's conscious recognition of the fact that its survival and sustainability lies in its ability to channel its resources and adapt its economic conditions to the external environment. In this regard, the Kingdom has launched Vision 2030 to balance the Possibilities and resources available to the State by taking advantage of available opportunities and dealing with future obstacles and challenges.

The Kingdom of Saudi Arabia is currently witnessing a period of great economic and social transformation as it seeks to transform from an oil-dependent country to a large variety and multiple sources of income to the state through reliance on industrial and service projects. The vision of the Kingdom of 2030 is based on three main axes: the vital society, the booming economy, and the ambitious country, to be among the leading countries in the world.

Here, the importance of social marketing is shown to seek to improve people's living conditions by promoting positive ideas and values in life and citizens' behaviors to serve the nation and achieve wellbeing for citizens (Calors, 2019). Kotler et al. (2002) defined social marketing as the use of marketing 
principles and techniques to reach the target audience for voluntary acceptance, rejection, modification or abandonment of behavior in favor of individuals, groups or society as a whole. Al-Bakri (2006) defined it as the other side of commercial marketing, which aims to change or modify the views, attitudes, and behavior of individuals and promote ideas or modify the attitudes of members of society for the benefit of society as a whole. Abdul Aziz (2011) agreed with this view that social marketing was defined as adaptation and adoption of commercial marketing activities as a means of encouraging behavioral change for target audiences. Ann et al. ( 2018) noted that social marketing in the early stages is a method used by social marketers to influence the adoption of policies and solutions. This change takes place through specific activities that are systematic and targeted at the interests of the individual, community, and society Hamilton et al. ( 2015). Dukes (1987) defines societal change as a change within society or a transformation or change in the social structure over a period of time.

Based on the above, social marketing in its modern concept, can through the promotion of ideas and provide citizens with knowledge about the future opportunities and challenges experienced by the Kingdom, and influence on the behavior of citizens and change their direction in the interest of citizens and society as a whole.

Therefore, the aim of the research is to identify the impact of social marketing activities to see the Kingdom of Saudi Arabia 2030 on citizen attitudes.

\section{Literature Review}

Social marketing has developed rapidly in recent years in social policy circles that seek to engage citizens in community work. The idea of social marketing began about half a century ago (Kotler, Zaltman, 1971) on social marketing in the possibility of using marketing principles and programs to promote ideas, attitudes, and behavior.

This article has linked social marketing and social change, and over time their perception of social marketing has shifted from selling ideas to focusing on changing the behavior of individuals (Andreasen, 1994).

Smith (2002) agreed with this definition and emphasized that social marketing can help to bring about social change by encouraging change in one's behavior. This is consistent with the view of many researchers (Helmig \& Thaler, 2010; Gordon et al., 2006). In the light of these implicit assumptions of social marketing, social marketing programs tend to contribute to the well-being of citizens, through educational campaigns to increase individuals' knowledge of the subject and their effective impact on their behavior (Citlali, C., 2018).

Sally et al. (2013) proposed four levels of social marketing. The first phase was to focus on the behavior to be changed, the second stage was the planning process, and the third phase (Andreasen, 2005) suggested three levels of social marketing ( with current - in the center of the current - against the current), the fourth stage is the integration of social media in the social marketing processes.

Many definitions of social marketing have continued to apply the principles and fundamentals of commercialization to social goals (Spotswood, French, Tapp, \& Stead, 2012; Gordon, 1974). Social marketers need to know the causes of the social problem so that social marketing solutions are more effective. Social marketing programs have been used extensively in marketing health campaigns to influence individuals in changing their unhealthy habits or preventing widespread diseases (Walter, 2011; Sonya et al., 2005; Dominic W. et al., 2016; Tanja K. et al. , 2014; V. Dao T., 2014,2018).

For example, health awareness campaigns in the Kingdom of Saudi Arabia about obesity and diabetes and the negative effects of these diseases on the health of the individual and society. 
Social marketing is seen as one of the branches of marketing science where it relies on the principles and fundamentals of marketing science to promote behaviors that have a positive impact on society at large (Matthew, 2012).

Marketing is concerned with boosting demand, anticipating needs and creating value, whether personal, social or economic. Andreasen (2012) predicted that social marketing may be the main branch of marketing in the future because it cares about the social market and contributes significantly to solving social challenges. Social marketing seeks to contribute by applying the principles and principles of marketing not only to study citizens' behavior but also to study the behavior of social service providers, policymakers, and stakeholders associated with social issues (Sally et al., 2013; Alan, 2002).

The importance of social marketing is to influence the knowledge, attitudes, and behavior of individuals, which are characterized by diversity and divergent differences over many years. Which requires a sustained and sustained effort to influence individuals, as they resist and reject any change in ideas, beliefs, and behaviors (Matthew, 2016).

If social marketing develops both theoretically and in practice, it is necessary to conduct ongoing dialogue and analysis on its nature. This research seeks to contribute to this dialogue in order to improve the understanding of the nature and contribution of social marketing in social policies and social change and to change the behavior of individuals.

\section{Attitudes}

For more than half a century, social psychology scholars have considered trends to be one of the basic concepts in the study of psychology, The trends reflect the individual's behavior in his words, his actions and his interactions with others, It also directs individual responses towards people and subjects in a way that is almost constant (Farr, 1996). No individual is born with any direction on an external subject, these tendencies are the result of the individual's contact with different external attitudes, which affect him in some way, This leads to the formation of certain special tendencies. In other words, man acquires his direction from the environment in which he lives (Zanati, 2015). The individual grows and expands his social relations and contacts with the different bodies in society or the social environment and the norms and trends in society are directed towards his behavior (Al-Slami, 1972).

The definitions of trends have been varied (Allport, 1954; Gibson, 1994) defined the trend as a state of mental and neurological readiness that is organized or experienced and directed to respond to relevant themes and attitudes. While Obaidat (2004) defined trends as "an expression of the internal feelings of individuals that reflect or reveal whether they have positive or negative tendencies toward a specific thing (brand of a commodity or service ... etc.).

Sultan (2003) defined the trend as a complex mental cognitive process represented by a relatively fixed tendency towards things and people. Anastasi (1982) has defined it as a fixed tendency to respond to a particular stimulus. (Nunnally, 1959) defined it as a tribal predisposition or a natural predisposition to respond negatively or positively to varying degrees of intensity towards a particular subject or group of individuals.

Despite the many definitions of trends, and regardless of the similarities or differences between them or about the complexity or ease of each, there is a definition that contains most of the basic elements that are mentioned in the different definitions of the previous trends that are an idea saturated with emotion tend to move different models of Behavior towards a particular class of attitudes, This definition shows that there are three components of the trend (Al-Lahlah, 2010): 


\section{Cognitive Component}

It is the first stage of the formation of the trend, and includes the intellectual frameworks of the individual any trends on any subject unless it has first of all knowledge of it, not necessarily full of it, the trends of ideas and beliefs can be acquired and modified, and the individual and develop through the experience and interaction with the surrounding environment.

\section{The Emotional Component}

The knowledge that an individual is about a subject must be associated with a feeling about it and that this feeling is not formed unless knowledge is formed first. And that the nature of the feeling that is generated on a subject depends on the nature of the relationship between this subject and the other goals that the person sees important and therefore the feeling becomes positive towards any subject if that leads to the achievement of positive goals and vice versa (Zanati, 2015). The emotional component is called the orthodontic component because it relates to the positive or negative human evaluation of things and ideas.

\section{Behavioral Component}

This component means that if a person has knowledge of a subject, followed by a specific (positive/negative) feeling, he or she becomes more likely to behave in a specific manner. It is necessary to distinguish between the behavioral tendency and the actual behavior. The first expresses the desire for behavior, the second symbolizes the real act. We may desire many things in our lives, but we do not achieve them, and this is the fundamental difference between them (Maghrebi, 2016).

Note that all elements of the direction can be overlapping in their relationship and that each element has an effect on the overall direction, and on the other elements.

\section{Social Marketing and Changing Trends}

The process of changing trends is easy and easy. As long as the trends are educated and acquired, changing them or replacing them is desirable. Instead, trends tend to prove and resist change. Although changing directions is complex and difficult, it is not impossible (Matthew W., 2016). Trends can change and trends can be reversed by following social marketing methods and campaigns that play an active role in changing the behavior of individuals (Hastings, 2007; Kotler \& Lee, 2007). The individual seeks to change trends to better deal with the environment, or to achieve self-satisfaction. Because of the unstable conditions and variables operating in the environment surrounding the individual, this is reflected in the different ways in which the individual understands the things and circumstances surrounding him.

There is no doubt that the difference in the perceptions of the individual, may also lead to the instability and regularity of thought processes that take place within it. The former aspects of perceptions and thinking processes on the individual are reflected in the generation of situations of unease and anxiety, which leads to the finding of appropriate ways to overcome them. The methods used by individuals to use in this case are to change the directions to conform to the behavior that is aware of the prevailing factors Around him.

Social marketing is a set of tools or activities that are used by a party in order to influence the behavior of another party in order to change behavior, whether positive or negative.

\section{The Vision of Saudi Arabia 2030 (Official website of the Saudi Ministry of Foreign Affairs, 2018)}

King Salman Bin Abdul Aziz Al Saud has established the Council of Economic and Development Affairs on January 29, 2015, which is subordinate to the Saudi Council of Ministers. The Council is chaired by the Prince Mohammed bin Salman bin Abdulaziz Al Saud. The Council for Economic Affairs and Development is the first of its kind in the country. The economy is not isolated from development. There 
will be no development without a well economy. The Council aims to shape the future of the Kingdom and makes new funds on the country in the coming years, Other than Exports of oil. This makes the ministries of economic, financial, social and educational affairs more connected.

The Council for Economic and Development Affairs submits to the Saudi Council of Ministers a proposal to see the Kingdom during the period between 2016 and 2030. The vision in its ambitious plan has focused on several points:

- Sovereign Fund: The Kingdom will convert the Saudi Public Investment Fund into a sovereign fund with assets estimated at $\$ 2$ trillion to $\$ 2.5$ trillion, making it the largest sovereign wealth fund in the world, with more than $10 \%$ of the investment potential in the world, More than $3 \%$ of global assets.

- Freedom from oil: Saudi Arabia can live without oil by 2020 and can achieve this economic plan even if the price of oil is thirty dollars or less, and it is almost impossible to break the price of oil thirty dollars on the demand of the world. The plan aims to increase non-oil revenues sixfold from about $\$ 43.5$ billion a year to $\$ 267$ billion a year and aims to increase the share of non-oil exports from $16 \%$ of GDP to 50\% of GDP. Saudi Arabia is seeking to improve its position among the top 15 economies in the world, instead of its current 20th position. In terms of energy sources, Saudi Arabia will establish a huge solar power complex in the north of the country. Saudi industries will focus on strengths and avoid weaknesses such as scarce water resources by channeling investment into Egypt and Sudan.

- Aramco's IPO: Aramco will be listed on the stock exchange and the proceeds from the IPO will be financed by the Saudi sovereign fund and Aramco is part of the key economic vision keys. It means that it must announce its lists and become under the control of all Saudi banks, all Saudi analysts and thinkers, and all the international banks, expecting Aramco to total more than $\$ 2$ trillion.

- Thirty million pilgrims: Saudi Arabia plans to increase the number of pilgrims annually from 8 million to 30 million by 2030. Infrastructure development work such as Jeddah's new airport and Taif airport will support the plan, as well as the development of infrastructure in Mecca and the investment of land around the Haram al-Makki. And that Saudi Arabia will establish the largest Islamic museum in the world and will be based in Riyadh, so as to allow non-Muslims to visit.

- Employment and Private Sector: The plan aims to increase the participation of women in the labor market from $22 \%$ to $30 \%$, and reduce the unemployment rate among Saudis from $11.6 \%$ to $7 \%$. The Kingdom is seeking to increase the contribution of the private sector to GDP from $3.8 \%$ currently to $5.7 \%$.

- Military industry: Saudi Arabia is in the process of establishing a government-owned military holding company to be launched later in the Saudi market.

- Housing and Projects: The Saudi government will restructure the housing sector to help raise Saudi ownership. Infrastructure spending will continue, but the economic vision of 2030 will not require high government expenditure. Saudi Arabia will establish a government project management office that will record all plans and objectives, begin to turn them into figures and measure periodic performance and monitor the alignment of the work of government agencies, government plans, and government programs to achieve the goals.

- anti-Corruption: The plan calls for strengthening the fight against corruption.

In order to achieve the ambitious goals of the vision of Saudi Arabia 2030, the need to launch the national transformation program at the level of 24 government agencies based on the economic and development sectors in the first year of the program was approved by the Council of Ministers on 7 June 2016. The program contains strategic objectives related to interim targets up to 2020, and the first phase of the initiatives launched from 2016 to achieve those goals and targets, to be followed by stages that include others on an annual basis.

Which means that Saudi Arabia will move through this vision to the stage of the knowledge economy, diversification of sources of income through creativity and innovation, and it is also possible to take advantage of existing financial resources through new investments and safe. 
This transformation will affect individuals within the community, as it requires changing citizens' attitudes and behavior to meet these challenges and interact with them positively, through the use of social marketing to make these changes in trends and patterns of consumer behavior or career and even intellectual in order to realize the importance of this transformation.

\section{Research Framework}

Based on previous literature, this study presents a framework for research that links the dimensions of Social Marketing with Attitudes as shown in Figure I. In this framework, Attitudes consists of three dimensions: Cognitive component, Emotional component, and Behavioral component.

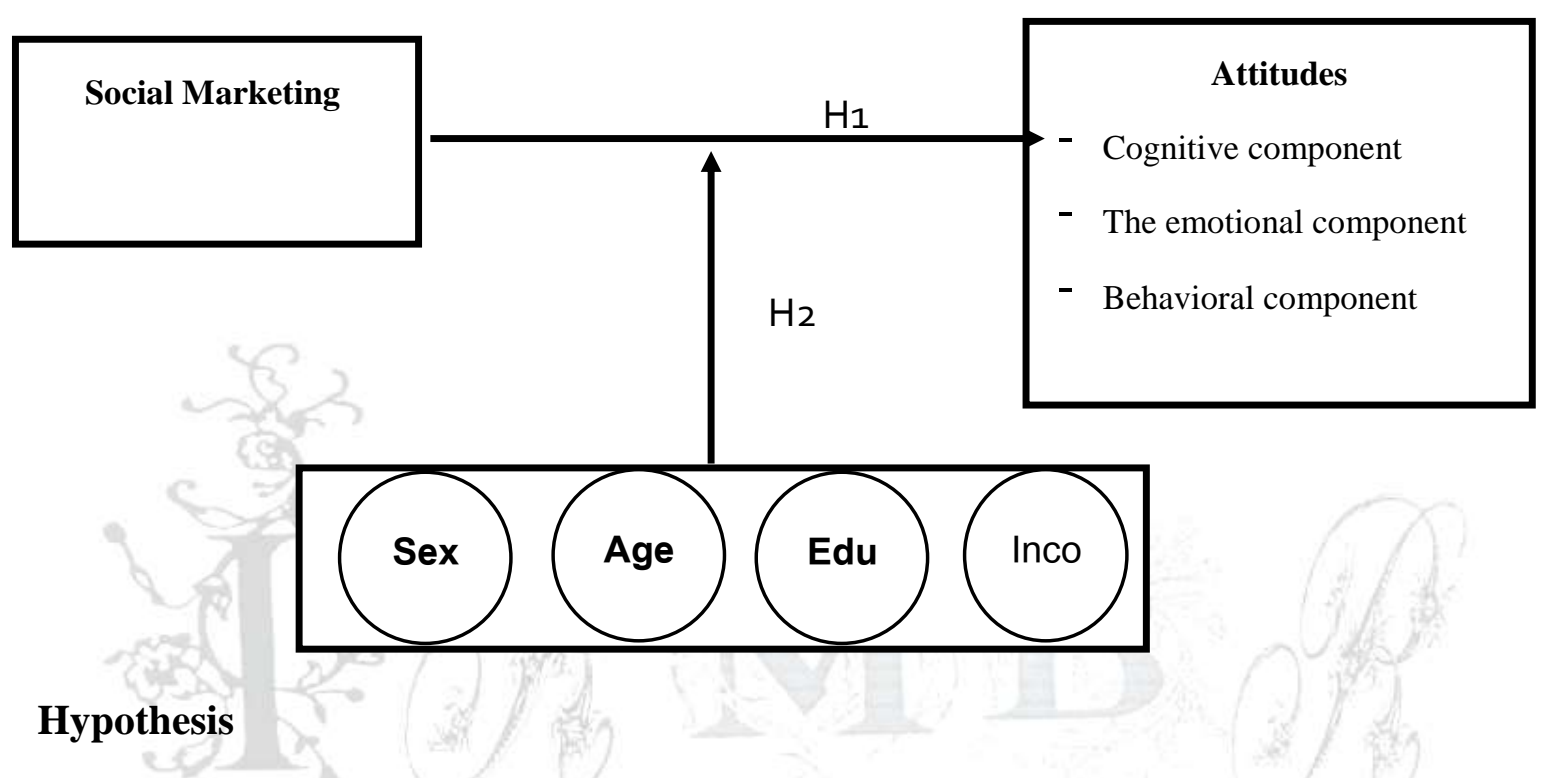

H1: There is a statistically significant effect at 0.05 level of social marketing activities for the Kingdom's 2030 vision on the Attitudes of the citizen.

H1.1: There is a statistically significant effect at 0.05 level of social marketing activities for the Kingdom's 2030 vision on Cognitive component of the citizen attitudes.

H1.2: There is a statistically significant effect at 0.05 level of social marketing activities for the Kingdom's 2030 vision on the emotional component of the citizen.

H1.3: There is a statistically significant effect at 0.05 level of social marketing activities for the Kingdom's 2030 vision on the behavioral component of the citizen.

H2: There are significant differences at the level of significance 0.05 in the attitudes of the Saudi citizen to the vision of the Kingdom 2030 according to their demographic characteristics.

H2.1: There are statistically significant differences at the level of significance of 0.05 in the attitudes of the Saudi citizen to the vision of the Kingdom 2030 according to the gender variable.

$\mathrm{H} 2.2$ : There are significant differences at the level of significance 0.05 in the directions of the Saudi citizen to the vision of the Kingdom 2030 according to the age variable.

$\mathrm{H}$ 2.3: There are significant differences at the level of significance 0.05 in the directions of the Saudi citizen to the vision of the Kingdom 2030 according to the variable level of education.

H2.4: There are significant differences at the level of significance 0.05 in the directions of the Saudi citizen to the vision of the Kingdom 2030 according to the income variable. 


\section{Questionnaire development and Sampling}

After reviewing the scientific literature from books, researches, periodicals, and previous studies related to the problem of research, a survey list was prepared on the impact of social marketing activities on 2030 on citizen attitudes.

The Questionnaire consisted of three sections:

Section I: The first part is demographic information about the respondent (gender, age, income level, educational level) (Q1-4).

The second part is a question on the arrangement of the most important means of communication in providing information about the vision of 2030 from the point of view of citizens (Q5 - 12).

Section II: The social marketing activities used to change the attitudes of citizens (Q13- 17).

Section III: the attitudes of citizens towards social marketing activities and their behavior towards them and divided into (cognitive component, the emotional component, behavioral component) (Q18- 26).

The research sample refers to a model that contains part of the original community units concerned with the research and is represented. So that the common characteristics of this researcher enriches the study of all members of the community and satisfied with a soft sample of members of society (Kandilji, 2002).

Exploration sample: The researcher conducted a survey to verify the clarity of the items of the research tool and its instructions. The research tool was applied to a soft sample of 15 people. The sample did not include the final application sample. As a result of the exploratory study, Pronounced and understood, thus bringing the final form to the list.

Sample final application: The researcher used a random sample (Hafez Juma, 2009). The researcher worked to make the research sample homogeneous and representative of the majority of the citizens of the Kingdom of Saudi Arabia, where the list was distributed electronically through social media. The sample of the response was valid for analysis (200).

The researcher used a random sample to collect the data and distributed the electronic survey list to the citizens of Saudi Arabia through social media.

\section{Analysis and Results}

\section{Descriptive Statistical Analysis of the Study Sample}

The study sample was collected by electronic distribution of the questionnaire on social media, which is addressed to the Saudi citizen in relation to the impact of social marketing activities to the vision of the Kingdom 2030 on the citizen's attitudes.

Table I presents the demographics of the sample. the number of males is ( $88 \%$ percent of total respondents), while the number of females is $(12 \%)$. The age group that contributes most to the research is the age group between 18 and 30 years ( $49 \%$ percent of total respondents), which represents the youth group, followed by the age group between 31 to 45 years $32.5 \%$. Finally, the age group is 45 years older than $18.5 \%$. The educational level of the majority of the sample is a Certification $61 \%$, followed by High School 31.5\%. The sample also included a 7.5\% Master and Ph.D. The most common categories in the research sample are less than 15000 SAR (56\%), followed by the category from 15000 to 30,000 SAR $35.5 \%$. Then the category more than 30000 SAR $8.5 \%$. 
Table 1 shows the demographic characteristics of the study sample.

\begin{tabular}{|c|c|c|c|}
\hline Construct & Classification & Number & $\%$ \\
\hline \multirow[t]{2}{*}{ Gender } & Male & 176 & 88 \\
\hline & Female & 24 & 12 \\
\hline \multirow[t]{3}{*}{ Age } & $18-30$ years old & 98 & 49 \\
\hline & $31-45$ years old & 65 & 32.5 \\
\hline & 46 and above & 37 & 18.5 \\
\hline \multirow[t]{3}{*}{ Education } & High School & 63 & 31.5 \\
\hline & Certification & 122 & 61 \\
\hline & Master / PhD & 15 & 7.5 \\
\hline \multirow[t]{3}{*}{ Income Level } & Less than $15000 \mathrm{SAR}$ & 112 & 56 \\
\hline & 15000 - 30000 SAR & 71 & 35.5 \\
\hline & More than 30000 SAR & 17 & 8.5 \\
\hline Note $: \mathrm{N}=200$ & & & \\
\hline
\end{tabular}

\section{Reliability Analysis}

The reliability of the measurements was tested by Alpha's Cronbach coefficient values for the purpose of determining the "stability of the tool". The stability and honesty coefficients by the survey axes were as follows:

Table II.The results of the reliability analysis to dimensions of the Social Marketing and Citizens' attitudes

\begin{tabular}{|c|c|c|}
\hline Variables & Items & Cronbach's alpha \\
\hline Social Marketing & 15 & 0.845 \\
\hline Citizens' attitudes & 9 & 0.767 \\
\hline
\end{tabular}

This means that there is a very high degree of internal consistency in the responses, which enables us to c

Table III. Results of Coefficient of correlation to dimensions the study.

\begin{tabular}{|c|c|c|}
\hline Variables & Spearmen Correlation & Sig. \\
\hline Social Marketing & 0.876 & 0.000 \\
\hline Citizens' attitudes & 0.765 & 0.000 \\
\hline
\end{tabular}




\section{Spearmen Correlation Matrix}

To determine the power and the direction of the linkage between factors the correlation coefficients of Spearman were applied. The estimated coefficients are shown as following (Table IV). The following results were obtained as shown in the following table:

Table IV. Spearman Correlation Matrix.

\begin{tabular}{|l|c|c|c|c|}
\hline Variables & Cognitive & emotional & Behavioral & Social Marketing \\
\hline Cognitive & 1 & & & \\
\hline emotional & 0.765 & 1 & & \\
\hline Behavioral & 0.879 & 0.814 & 1 & 1 \\
\hline Social Marketing & 0.876 & 0.885 & 0.893 & \\
\hline
\end{tabular}

The results of the Spearman correlation matrix indicate a significant positive relationship between Social Marketing (considered as the dependent variable) and the Attitudes defined by Cognitive, emotional, and Behavioral (considered as the independent variables) at $1 \%$ significance level.

\section{Regression Analysis}

Table V. Results of regression analysis and ANOVA .

\begin{tabular}{|l|c|c|c|c|c|c|c|c|}
\hline Variables & $\begin{array}{c}\text { Karl } \\
\text { Pearson's } \\
\text { Correlation } \\
\mathbf{R}\end{array}$ & $\begin{array}{c}\mathbf{R} \\
\text { Square }\end{array}$ & $\begin{array}{l}\text { Adjusted } \\
\text { R Square }\end{array}$ & $\begin{array}{c}\text { Std. Error of } \\
\text { the Estimate }\end{array}$ & \multicolumn{4}{|c|}{ ANOVA } \\
\hline Cognitive & 0.743 & 0.401 & 0.860 & 0.794 & 351.317 & 0.000 & 5.769 & 0.000 \\
\hline $\begin{array}{l}\text { The } \\
\text { Emotional }\end{array}$ & 0.756 & 0.413 & 0.891 & 0.712 & 375.122 & 0.000 & 4.987 & 0.000 \\
\hline Behavioral & 0.701 & 0.371 & 0.815 & 0.841 & 333.012 & 0.000 & 6.098 & 0.000 \\
\hline Total & 0.798 & 0.453 & 0.898 & 0.756 & 376.132 & 0.000 & 5.057 & 0.000 \\
\hline
\end{tabular}

Based on the results of the regression analysis, we find that the linear correlation coefficient in the independent variable (social marketing) is (0.698) and that the accuracy of the estimate of the dependent variable (citizen trends) is $45 \%$, and we find that the social marketing activities of the 2030 vision, $45 \%$ of the change in the attitudes of citizens of the sample items, and 55\% of the change in the attitudes of citizens is due to other factors. Karl Pearson's correlation coefficient is (0.698), which is a high percentage, indicating a relationship between social marketing activities and 2030 vision on citizen attitudes. An ANOVA analysis of the regression shows that the value of $F$ is 376.231 at a significant level $(0.05)$ and that the level of test significance is (0.000) that mean there is an impact of social marketing activities on the citizens' attitudes. The results of the t-test showed that the value of $t$ is equal to (5.057) at a significant level (0.000). From the above, it is clear that there is a statistically significant effect at 0.05 level of social marketing activities for the Kingdom's 2030 vision on the Attitudes of the citizen.

The impact of social marketing activities on citizens 'attitudes was examined through its three dimensions: the cognitive component, the emotional component, and the behavioral component. The coefficient of correlation of Karl Pearson to the three dimensions of citizens' attitudes towards social marketing activities 
for the Kingdom's Vision 2030 ranged between (0.701) and (0.743), indicating that there is a relationship between the variables (independent and dependent), which mean, whenever the social marketing activities changed, the citizen's attitudes were changed according to the cognitive, emotional, and behavioral components, as well as the emotional component of the citizen. The ANOVA analysis of the statistical significance of these sub-hypotheses shows that the value of $F$ is between $(333,012)$ and $(375.122)$, the value of $(0.491)$ and $(6,098)$ at a significant level $(0.05)$. The values of R2 are between $(0.371)$ and $(0.413)$ and are close in the three dimensions of the citizens'

\section{One Way ANOVA analysis}

This analysis measures the variance between Saudi Arabia citizens Attitudes Towards Kingdom Vision 2030 According to Demographic Characteristics

Table VI.The results of One Way ANOVA analysis

\begin{tabular}{|ll|c|c|c|c|}
\hline & & df & Mean Square & f & Sig. \\
\hline Sex & Between Groups & 198.1 & 3.112 & 1.475 & 0.201 \\
& Within Groups & & 1.760 & \\
\hline Age & Between Groups & 197.2 & 13.987 & 13.395 & 0.000 \\
& Within Groups & & 1.378 & \\
\hline \multirow{2}{*}{ Edu. } & Between Groups & 178.3 & 1.253 & 6.543 & 0.000 \\
& Within Groups & & 10.776 & 8.760 & 0.000 \\
Income & Between Groups & 183.8 & 1.232 & & \\
\hline
\end{tabular}

Based on the results of one way ANOVA analysis of the sex variable, the result of the (F) test was (1.475) at a significant level (0.201) which is greater than the significance of the research which is $(0.05)$ There is no difference in the trends of the sample to see 2030 according to their gender. Therefore, the first subhypothesis and the acceptance of the alternative hypothesis will be rejected as "there are no statistically significant differences at the level of significance of 0.05 in the attitudes of the Saudi citizen to the vision of the Kingdom 2030 according to gender variable."

For the age variable, the result of the $(F)$ test was (13.395) at a significant level (0.000) which is less than the significance of the research, which is $(0.05)$, So this sub-rule will be accepted. As for the income level variable, the result of the $(F)$ test was (6.543) at a significant level (0.001) which is less than the significance of the research which is $(0.05)$ Level of income, so this sub-assumption will be accepted.

For the variable of educational levels, the result of $(\mathrm{F})$ was 8.760 at a significant level (0.000) which is less than the mean of the research which is (0.05) Educational level, so this sub-assumption will be accepted. From the above, it is clear that the second main hypothesis is that "there are statistically significant differences in the level of significance of 0.05 in the attitudes of the Saudi citizen to the vision of the Kingdom of 2030 according to their demographic characteristics," with the exception of the sex variable.

\section{Discussion and Conclusion}

Social marketing cares and makes a significant contribution to solving social challenges. Through the study of the behavior of citizens, social service providers, political decision-makers, and stakeholders associated with social issues by adopting programs to promote ideas, attitudes, and behavior to serve the individual and society. 
The main findings of the researcher include the following:

- The use of social marketing in the process of social change has become necessary in the contemporary challenges posed by globalization and its cultural and economic dimensions to developing societies and this is consistent with the study (Khalaf et al., 2017).

- The results of the research show that the social marketing activities of the vision of the Kingdom of 2030 have contributed to influencing citizens 'attitudes. This indicates that the adoption of the idea of social marketing by the Kingdom will help the positive change of citizens' attitudes and success of The vision. (Jeff F. et al., 2015), (Stephen D., 2010) ,(Najem, 2016 ).

- In general, there is a total impact of social marketing activities to see the Kingdom of 2030 on the citizen's attitudes and this corresponds with (Mujahid et al., 2017) (Kotler and Roberto, 1989) (Judith M. et al., 2014).

- The results showed that the change in the marketing activities of the 2030 vision led to change first in the emotional component. This indicates the effect of the Saudi citizen emotionally on the vision of the Kingdom 2030, and this is different with (Katherine et al. 2016), who concluded that the emotional value has no effect on the behavior. (100\% of the sample has knowledge of the vision and its logo, while $45 \%$ have no knowledge of the contents of the vision and this percentage was concentrated in the youth group from 18-30 years), And finally comes the behavioral component.

- There is a difference in the attitudes of citizens about the vision of 2030 in terms of demographic variables (age, income), and the current research is consistent with the study of both (Mujahid et al. 2015) and (Mujahid et al. 2017) and the current research with them to prove the different trends of citizens in terms of variable (Educational level), which did not prove in their studies, as the research differed with the study (Taha, 2016), which did not prove any impact on the demographic factors in his study.

- Research shows that there is no difference in the attitudes of citizens in terms of the variable (gender) and this is consistent with the studies of both (Mujahid et al. 2015) and (Mujahid et al. 2017).

- Social networking sites ranked first by $85 \%$ in the most important communication medium in providing information on the 2030 Vision from the point of view of citizens, followed by $60 \%$ by television. While brochures ranked the last in the most important means from the point of view of citizens. This corresponds to the study (Jeanine P.D. G. et al., 2014)

\section{References}

Abdul Aziz, Sami, (2011) "Social and Political Marketing," Dar Nahdet Misr, Cairo.

Alan R. Andreasen ، (2002 ) "Marketing Social Marketing in the Social Change Marketplace ", Journal of Public Policy \& Marketing, Spring, Vol. 21 (1),pp. 3-13 .https://doi.org/10.1509/jppm.21.1.3.17602

Al-Daqis, Mohamed, (1987) "Social Change between Theory and Practice" Dar Al Majdalawi Publishing and Distribution, Amman, Jordan.

Al-Lahlah, Ahmad Ahmad Abdullah, (2010), "Organizational Behavior in Contemporary Organizations", Dar Al-Khouli for Printing, Tanta, Egypt.

Allport, Gordon W.(1954) . The historical background of modern social psychology . In lindzey Gardner (Ed) . handbook of social psychology . London : Addison - Wesley publishing company

Anastasi,A.(1982).Psychological Testing 5th ed .New York: Millan Publishing Company Inc.

Andreasen, A. (2012), "Rethinking the relationship between social/nonprofit marketing and commercial marketing", Journal of Public Policy and Marketing, Vol. 31 No. 1, pp. 36-41. https://doi.org/10.1509/jppm.09.035 .

Andreasen, A. R. (1994). Social marketing: Its definition and domain. Journal of Public Policy and Marketing, Vol. 13, No.1, pp.08-114.https://doi.org/10.1177/074391569401300109

Andreasen, A.R. (2005), Social Marketing in the Twenty-first Century, Sage, Thousand Oaks, CA. 
Ann-Marie Kennedy, Joya A. Kemper, Andrew Grant Parsons, (2018) "Upstream social marketing strategy", Journal of Social Marketing, Vol. 8 Issue: 3, pp.258-279, https://doi.org/10.1108/ JSOCM03-2017-0016.

Bakri, Tamer (2006) "Foundations and Contemporary Concepts", Dar Al Yazuri, Amman, Jordan.

Carlos Oliveira Santos, (2019) "A national policy process on social marketing", Journal of Social Marketing, https://doi.org/10.1108/JSOCM-03-2018-0032

Citlali Calderon, (2018) "The importance of shared beliefs for social marketing programmes", Journal of Social Marketing, https://doi.org/10.1108/JSOCM-01-2018-0013

Cooper D. R. , Schindler P.S. ,(2011), Business Research Methods ,11th end, McGraw Hill/Irwin , New York.

Dominic Wettstein, L. Suzanne Suggs, (2016) "Is it social marketing? The benchmarks meet the social marketing indicator", Journal of Social Marketing, Vol. 6 Issue: 1, pp.2-17, https://doi.org/10.1108/JSOCM-05-2014-0034

Dweidar, Abdel Fattah (2006), reference in research methods in psychology and the techniques of writing scientific research. 4th edition, Dar Al Maarefah, Alexandria, Egypt.

Fatih Majahdi, Cheraf Brahimi (2015), "Study of Algerian Consumer Trends Towards ENIE", El-Rada Journal o for Business Economics, No. 1, Algeria.

Gardon Wills, (1974) "Marketing's Social dilemma", European Journal of Marketing, Vol. 8 Issue: 1, pp.414, https://doi.org/10.1108/EUM0000000005073.

Gordon, Ross; McDermott, Laura; Stead, Martine and Angus, Kathryn (2006). The effectiveness of social marketing interventions for health improvement: what's the evidence? Public Health, 120(12) .https://doi.org/10.1016/j.puhe.2006.10.008 .

Hamilton Coimbra Carvalho, Jose Afonso Mazzon, (2015) "A better life is possible: the ultimate purpose of social marketing", Journal of Social Marketing, Vol. 5 Issue: 2, pp.169-186, https:// doi.org/10.1108/JSOCM-05-2014-0029

Hastings, G. (2007), Why Should the Devil have all the Best Tunes?, Butterworth-Heinemann, Elsevier, London.

Helmig, B. and Thaler, J. (2010), "On the effectiveness of social marketing - what do we really know?", Journal of Nonprofit \& Public Sector Marketing, Vol. 22 No. 4, pp. 264-287. https://doi.org/10.1080/10495140903566698 .

Hjaila, Rahali (2010) "Social Change in Algerian Society - Concept and Models, Journal of the Faculty of Arts, Humanities and Social Sciences, University of Mohammed Khedr Biskra, No. 7.

Hozifa Zeidan Khalaf, Amjad Hamid Ismail (2017), Social Marketing and its Role in Changing Social Values, Journal of the College of Basic Education, Volume 23, Number 97, Iraq.

http://vision2030.gov.sa_السعودية_روية_/2030

http://www.mofa.gov.sa/Vision2030/Pages/default.aspx

https://doi.org/10.1177/1524500413517666

https://www.tech-wd.com/wd/2017/06/10//

James L. Gibson, John M. Irancevich, and Jame Jr. (1994). Organization : Behavior, Structure H. Donnelly, and Processes, 11th ed. (Homewoal III. IRWIM, P. 114.

Jeanine P.D. Guidry, Richard D. Waters, Gregory D. Saxton, (2014) "Moving social marketing beyond personal change to social change: Strategically using Twitter to mobilize supporters into vocal advocates", Journal of Social Marketing, Vol. 4 Issue: 3, pp.240-260, https://doi.org/10.1108/JSOCM02-2014-0014

Jeanine P.D. Guidry, Richard D. Waters, Gregory D. Saxton, (2014) "Moving social marketing beyond personal change to social change: Strategically using Twitter to mobilize supporters into vocal advocates", Journal of Social Marketing, Vol. 4 Issue: 3, pp.240-260, https://doi.org/10.1108/JSOCM02-2014-0014

Jeff French, Rebekah Russell-Bennett, (2015) "A hierarchical model of social marketing", Journal of Social Marketing, Vol. 5 Issue: 2, pp.139-159, https://doi.org/10.1108/JSOCM-06-2014-0042 
Judith Madill, Libbie Wallace, Karine Goneau-Lessard, Robb Stuart MacDonald, Celine Dion, (2014) "Best practices in social marketing among Aboriginal people", Journal of Social Marketing, Vol. 4 Issue: 2, pp.155-175, https://doi.org/10.1108/JSOCM-08-2013-0056

Judith Madill, Libbie Wallace, Karine Goneau-Lessard, Robb Stuart MacDonald, Celine Dion, (2014) "Best practices in social marketing among Aboriginal people", Journal of Social Marketing, Vol. 4 Issue: 2, pp.155-175, https://doi.org/10.1108/JSOCM-08-2013-0056.

Juma, Hafez (2009), Fundamentals and Methods of Scientific Research in Management, Cairo, Arab Organization for Administrative Development.

Kambiz Heidarzadeh Hanzaee, Mona Sadeghian, Saeed Jalalian, (2019) "Which can affect more? Cause marketing or cause-related marketing", Journal of Islamic Marketing, Vol. 10 Issue: 1, pp.304-322, https://doi.org/10.1108/JIMA-04-2016-0028

Katherine Butler, Ross Gordon, Kate Roggeveen, Gordon Waitt, Paul Cooper, (2016) "Social marketing and value in behaviour?: Perceived value of using energy efficiently among low income older citizens", Journal of Social Marketing, Vol. 6 Issue: 2, pp.144-168, https://doi.org/10.1108/ JSOCM07-2015-0045

Ken Peattie, Sue Peattie ،2009) ,Social marketing: A pathway to consumption reduction? , Journal of Business Research, volume 62 issue 2, pp. 260-268. https://doi.org/10.1016/j.jbusres.2008.01.033

Kotler P, Lee NR.(2007), Social marketing: influencing behaviors for good. 3rd ed. Thousand Oaks, CA: Sage Publications .

Kotler P, Roberto N, Lee N. 2002. Social Marketing: Improving the Quality of Life. Thousand Oaks, CA: Sage .

Kotler, P. \& Roberto, E. (1989).“ Social marketing: Strategies for changing public behaviour“. New York: Free Press.

Kotler, P. and Zaltman, G. (1971), "Social marketing: an approach to planned social change", Journal of Marketing, Vol. 35. No 3, pp. 3-12.https://doi.org/10.1177/002224297103500302 .

Maghrby , Mohamed Elfatih Mahmoud Bashir, (2016), "Organizational Behavior", Al-Rashed Library, Riyadh, Saudi Arabia.

Matthew Wood ( 2016), Social Marketing for Social Change, social Marketing Quarterly, Vol. 22 No 2 PP 107-118.https://doi.org/10.1177/1524500416633429.

Matthew Wood (2012), "Marketing social marketing”, Journal of Social Marketing, Vol. 2 No. 2, pp. 94102. https://doi.org/10.1108/20426761211243937.

Mujahid, Fatih, Salima Makhlouf, Kawthar Haj Na'as, (2017), "The Effect of Social Marketing on Algerian Consumer Trends - A Comparative Field Study of Telecommunications Operators in Algeria - Mobilis, and Oredo", Algerian Journal of Economic Development Issue 7 - December, Algeria.

Najem , Mjeeda Mohamed, (2016), "Social Marketing in the Social Work Profession," Journal of the University of Sharjah for Humanities and Social Sciences, Vol. 13, No. 1, June, UAE.

Nunnally ,Jum E.(1959).Tests ,Measurements, Assessment and Prediction. New York: Mc. Graw-Hill Book Company.

Obaidat, Mohamed Ibrahim (2004), Consumer Behavior, 4th edition, Dar Wael Publishing and Distribution, Amman, Jordan.

Qandilji, Amer (2002), Scientific Research and the Use of Traditional and Electronic Sources of Information, First Arabic Edition, Dar Al Yazouri Scientific Publishing and Distribution, Amman, Jordan

Sally Dibb, Marylyn Carrigan, (2013) "Social marketing transformed: Kotler, Polonsky and Hastings reflect on social marketing in a period of social change", European Journal of Marketing, Vol. 47 Issue: 9, pp.1376-1398, https:// doi.org/10.1108/EJM-05-2013-0248

Salmi, Ali (1972), Human Behavior in Management. Cairo, Gharib's Library .

Smith, W. A. (2002). Social marketing and its potential contribution to a modern synthesis of social change. Social Marketing Quarterly,Vol. 8, No.2, pp. 46-48.https://doi.org/10.1080/15245000212556 .

Sonya Grier and Carol A. Bryant , (2005) “ SOCIAL MARKETING IN PUBLIC HEALTH “ Annual Reviews of Public Health, Vol. 26 Issue: 1, pp.319339.https://doi.org/10.1146/annurev.publhealth.26.021304.144610 . 
Spotswood, F., French, J., Tapp, J. and Stead, M. (2012), "Some reasonable but uncomfortable questions about social marketing”, Journal of Social Marketing, Vol. 2 No. 3, pp. 163175.https://doi.org/10.1108/20426761211265168 .

Stephen Dann (2010), Redefining social marketing with contemporary commercial marketing definitions , Journal of Business Research, volume 63 issue 2, pp., 147-153 .

Taha, Morteza Ahmed Hassan, (2016), "The Effect of Social Marketing on Increasing the Marketing Share in the Telecommunications Sector in Sudan", Master Thesis, Faculty of Graduate Studies and Research, Rabat National University, Sudan.

Tanja Kamin, Thomas Anker, (2014) "Cultural capital and strategic social marketing orientations", Journal of Social Marketing, Vol. 4 Issue: 2, pp.94-110, https://doi.org/10.1108/JSOCM-08-2013-0057.

V. Dao Truong (2014), Social Marketing: A Systematic Review of Research 1998-2012, Social Marketing Quarterly, Vol. 20(1) 15-34.

V. Dao Truong, Stephen Graham Saunders, X. Dam Dong, (2018) "Systems social marketing: a critical appraisal", Journal of Social Marketing, https://doi.org/10.1108/JSOCM-06-2018-0062

Walter Wymer, (2011) "Developing more effective social marketing strategies", Journal of Social Marketing, Vol. 1 Issue: 1, pp.17-31, https://doi.org/10.1108/20426761111104400.

Zanati, Mohamed Rabie, (2015), "Organizational Behavior - Behavior of Individuals and Groups in Organizations", Al Mutanabi Library, Dammam, Saudi Arabia.

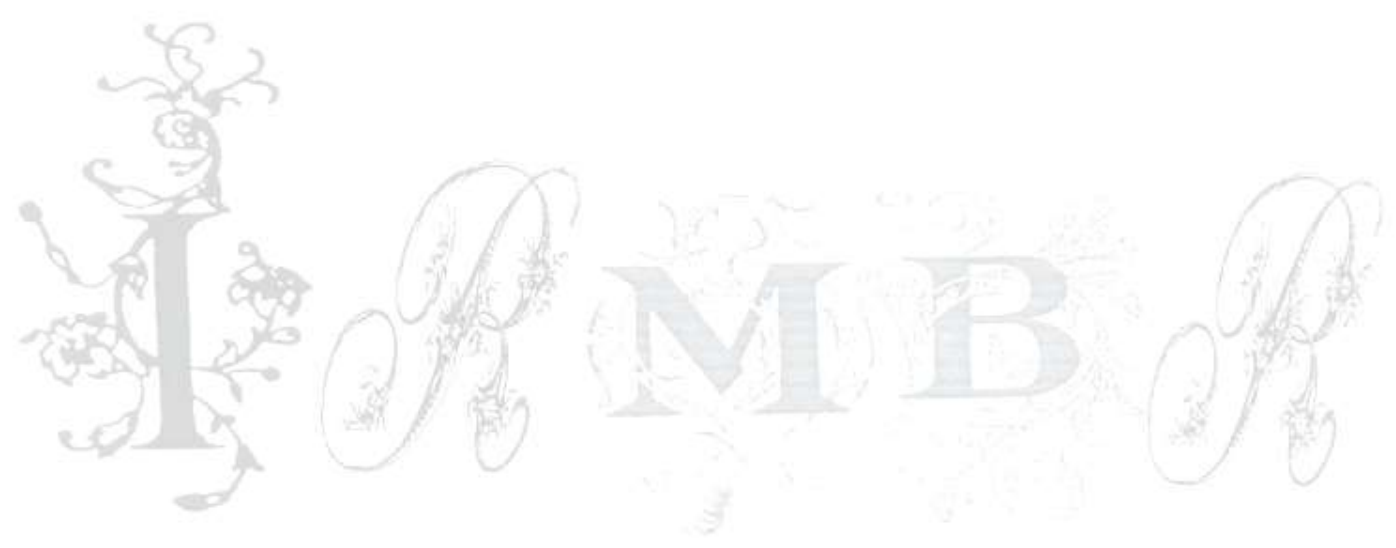

